\title{
STRUCTURAL ANALYSIS OF INWARD FOREIGN DIRECT INVESTMENT IN LATVIA
}

\author{
Aleksejs Jurša ${ }^{1}$ \\ Mg. oec. \\ Faculty of Business, Management and Economics, University of Latvia
}

\begin{abstract}
The aim of this article is to investigate the activity of foreign direct investors in Latvia and find out what is the main source of financing for foreign investors new investments or reinvested earnings. In order to achieve the set goal and test the hypothesis, the methodology of Sixth Edition of the International Monetary Fund's Balance of Payments and International Investment Position Manual was used to define the types of foreign direct investment. This methodology was adapted to Latvian data. At the request of the author, Ltd Lursoft IT selected business data on all registered companies with foreign capital in Latvia since 2005 and aggregate data were used in the analysis. Foreign direct investment in Latvia flows mainly in the form of reinvested earnings, due to the profit earned from operating activities in Latvia. While new investments or greenfield investments in equity is lower compared to the amount of reinvested earnings. The results of the study reflect the business results of foreign direct investors in Latvia, as well as their actions in relation to the earned profit from operating activities. These results could be used by the Ministry of Economics of the Republic of Latvia and the Investment and Development Agency of Latvia to improve Latvia's investment environment and implement a more effective investment attraction strategy.
\end{abstract}

Keywords: Latvia; Foreign Direct Investment; Greenfield Investment; Brownfield Investment; Investment Climate

\section{Introduction}

In today's world of globalisation and high-tech technology, the growth of the country's economics is largely linked to the rapid introduction of modern, state-of-the-art production tools and technologies. Therefore, many countries nowadays, especially those undergoing economic transition, face a dire need to activate investment operations to increase competitiveness, modernise existing production structures and create new products, which is especially important in today's saturated market and rapidly changing conditions. Foreign direct investment (FDI) is a type of

1 Contact: Aleksejs Jurša; aleksej.jursa@gmail.com; Faculty of Business, Management and Economics, University of Latvia, Riga, LV-1050, Latvia. 
foreign investment aimed at establishing a new, independent company or expand an existing business through merger or takeover. Today, these investments have become one of the most important aspects of the development of international companies. FDI has also been linked to a number of economically beneficial developments. They are a source of new technologies and innovations, as well as a source of new jobs and an improvements in infrastructure. Thus, FDI is an important financial instrument with a significant role in the development of economics, especially in countries where the local capital is limited. Such investments are subject to a variety of difficulties and opportunities and, therefore, FDI-related research will continue to be relevant and important in the future.

Keeping in mind the unsuccessful approach leading up to 2008 (or before Latvia's economy was hit by recession), prudent bank crediting policy prevents companies from obtaining the necessary flow of money for investments. The existing approach of the banks in issuing loans is much more careful. On the other hand, other types of financial instruments are limited; risk capital is very poorly developed in the Latvian market, but the issuance of bonds is relatively expensive. Prudent commercial banking policy is not the only reason for weak local investment activity. Based on a study by Stockholm School of Economics in Riga on the shadow economy in the Baltic States, in Latvia, the shadow economy in 2019 was $23.9 \%$ of GDP which is a high number. The largest share of the shadow economy in Latvia is accounted for by envelope wages and non-declared income, respectively $44.1 \%$ and $32.0 \%$ of the total shadow economy in Latvia (Stockholm School of Economics, 2020). It is also important to note that out of all companies that submitted annual reports to Lursoft IT Ltd in 2019 (109.5 thousand companies) only 66 thousand had an annual turnover up to 12 million euro. In turn, only $56.8 \%$ of these companies have positive equity and positive profits. Consequently, it can be concluded that the range of potential companies to which commercial banks can issue loans to is limited. Thus, it must be concluded that the faster investment development is hindered by both demand and supply factors. In the light of low investment activity, it is very difficult to increase productivity and reduce unemployment on a national scale. Until then, foreign direct investment can supplement local capital, thus solving existing problems and "building" a competitive economy in the long run.

The aim of this article is to evaluate the activity of foreign direct investors in Latvia, describing the economic indicators of companies for the last 15 years. Since the restoration of Latvia's independence, Latvia has attracted almost 16 billion euro of foreign direct investment. This corresponds to $52.3 \%$ of Latvia 's nominal GDP in 2019. There have been no studies on whether this significant inflow of financial resources was invested in the creation of new companies or the so-called "greenfield" investments 
were made or in the takeover of existing companies. Therefore, the main hypothesis of the research is to find out whether the current investment environment in Latvia is favourable for acquisitions of local companies by foreign investors, but not for setting up new businesses. The results showed that foreign direct investment in Latvia flows mainly in the form of reinvested earnings, due to the profit earned from operating activities in Latvia. New or greenfield investments in equity form are lower part of the total incoming FDI, which indicates that there is bottleneck in attractin new FDI. The annual reports of FDI enterprises were used for data processing.

\section{Literature review}

The initial studies in the field of FDI were conducted in the $19^{\text {th }}$ century, but these combined general notions incorporating the spheres of policy, economics and history. Overall, there are two approaches to studying investment roots, that is, approaches by F. Hayek and J. M. Keynes. The approach by F. Hayek (1941) relies on the fact that investments are viewed as moving to a state of equilibrium, because the optimum amount of investments depends on how fast something should be done (Hayek, 1941). Whereas capitalists are more interested in what would be the optimal amount of investment for a specific period of time. According to the theory by J. M. Keynes, the concept of optimal investment is linked not to "optimal adaptation" but to "optimal behaviour". In essence, Keynes's theory omits the issue of discussion about fluctuating accumulated capital, until much later it was brought to light by growth theorists (Keynes, 1936). Modern Neo-Keynesian and Post-Keynesian scholars sought to incorporate accumulated capital into Keynes' theory in order to obtain a "more complete" theory of macroeconomics.

Over the past 70 years, many researchers have tried to explain the phenomenon of FDI, while failing to crystallise a single, generally accepted theory of FDI. The Product life-cycle theory developed by R. Vernon was based on US investment. In general, this theory explains commodity exports and incoming FDI in Western Europe from the US between 1950 and 1970 (Vernon, 1966). This theory shows the change in the amount and geography of FDI depending on the product life cycle, from the invention of the product, to the export, to the establishment of manufacturing companies in the target country.

The theory of internationalisation is based on an explanation of the development of transnational companies and their motivation to perform FDI (Coase, 1937). Internalization theory goes beyond concentrating on transaction cost economizing to recognize a variety of strategic and managerial issues involved in internationalization, and to focus on managing the innovation process in its entirety (Buckley and Casson, 1976). The theory 
of internationalisation, suggests how the joint management of different production processes in different places can increase the demand for goods (Buckley and Casson, 2009). Transnational corporations with subsidiaries in several parts of the world but weak co-operation are less competitive than transnational corporations, which are able to integrate each subsidiary with a certain function in the overall production chain (Casson, 2000).

Taking into account the reality and complexity of multinational enterprises, especially from emerging economies, including both their successes and, in some cases, their lacklustre economic performance, a new internationalisation theory has developed over the last twenty years. The emphasis shifted from explaining the parameters that would stimulate firms to expand across borders, and investigating entry mode choice, to the multinational enterprises internal organization and their network capabilities (Verbeke and Kano, 2015). Globalization has modified the 'ecosystem' in which firms exist: globalization allows accelerated internationalization and new opportunities for domestic firms to become multinational enterprises (Narula, 2012). New theory focuses on managing interdependencies between economic actors located in different countries, and draws attention to the role of complementary resources of foreign actors that the multinational enterprises may require in order to enable the exploitation of its own firm-specific advantages (Hennart, 2009). In contrast to conventional, mainstream internalisation theory, the new internalisation theory focuses on the dynamics of international governance, whereby value creation hinges on successful knowledge recombination and governance choices are assumed to change over time (Verbeke and Kano, 2012). The theory of internationalisation was also widely commented on by J. Danning. Later, this theory became the basis for his eclectic paradigm.

The eclectic paradigm provides an explanation on how to rationally use resources and organise operations. It combines and integrates ownershipspecific $(\mathrm{O})$, location specific (L) and internalisation (I) factors in articulating the benefits of international production. The paradigm is intertwined with the theory of international trade $(\mathrm{L})$ from the macroeconomic point of view and theories of enterprise development from a microeconomic point of view (O and I) (Dunning, 1988). All three variables are important in determining the size and strategy of FDI. In general, the eclectic paradigm provides a broader view compared to other theories, explaining the necessity of FDI. The theory explains the causes of a firm's international expansion, arguing that the geographic extent ant the industrial element of foreign productions of multinational enterprises are determined by the interaction between three interdependent variables (Dunning, 2001). Over the last 30 years since the introduction of this theory the business environment has changed significantly, however the OLI model is still largely relevant. The eclectic paradigm has been extensively used to explain the growth 
of multinational enterprises in various industries and types of activity. However, the three variables (OLI) have been contested on the context of economic globalisation (Ribau et al., 2015). The eclectic paradigm, like other theories of FDI, has some limitations, however. First, the paradigm does not explicitly delineate the ongoing, evolving process of international production. FDI itself is a dynamic process in which resource commitment and production scale are changing over time. Second, the conventional wisdom seems inadequate in illuminating how geographically dispersed international production should be appropriately coordinated and integrated (Shenkar, 2007). To a large extent, the above range of questions can be extended to other theories too.

It can be concluded that there is no single theoretical explanation of the nature, flow volume and motivation of FDI. Each theory offers its own motivating and influencing FDI factors. Each investment project is individual, so none of the theories explain all the possible influencing factors, but gives an idea of general theoretical explanations.

An important issue in analysing FDI is the investment climate. Most of the explanations lead to the common conclusion that the investment climate is political, legal and institutional environment affecting the functioning of the market and risks associated with starting, operating, and closing a business (World Bank Group, 2015). The issue of the investment environment is focused on institutions and policies that affect the productivity of accumulated investments and the willingness to invest over a long period of time. Assessing the investment environment at the global level is a strategic issue, assessing the benefits and potential risks of specific investments in a particular country (Kahraman, 2011). Looking more closely at the investment environment, the author concludes that the factors that attract FDI largely have a common objective - to reduce costs through the economic advantages of another country, thus increasing profits. A larger market for product consumption contributes to cost reduction and improve resource efficiency. Therefore, a large market creates the opportunity to increase profit. Low labour costs are not always commensurate with high productivity and science-intensive technologies, but they have a significant impact on attracting FDI. Another important factor is exchange rate fluctuations and the stability of the tax policy of the recipient country, which directly affects the investor's profit.

There are different classifications of foreign investments in modern academic literature. Foreign investment can be divided into two large groups, namely portfolio investment and direct investment. Portfolio investment is the acquisition of a foreign company securities with the aim of increasing the value of the initial capital, as well as receiving dividends. While, the main purpose of foreign direct investment is to acquire a qualifying holding in a foreign company in order to participate 
in the management of the company and in the process of making strategic decisions (Pike and Neale, 2006).

Based on IMF's Balance of Payments and International Investment Position Manual, foreign direct investment is a category of cross-border investment associated with a resident in one economy having control or a significant degree of influence on the management of an enterprise that is resident in another economy. Direct investment implies a long-term relationship between a direct investor and direct investment enterprise. Immediate direct investment relationships arises when a direct investor directly owns equity that entitles it to 10 percent or more of the voting power in the direct investment enterprise (International Monetary Fund, 2009). The components of direct investment are equity and debt instruments.

Equity is a financial asset that is a claim on the residual value of a corporation, after the claims of all creditors have been met. It incorporates listed shares and other equity. The acquisition of the historic investment and new investments in a direct investment enterprise are included. Reinvested earnings are a part of the enterprise's profit or loss that belongs to the direct investor in proportion to its holding and remains at the disposal of the direct investment enterprise and are reported under direct investment separately from equity. While debt instruments are trade, borrowing and lending transactions conducted between direct investors and direct investment enterprises (Bank of Latvia, 2020).

Depending on the amount of foreign direct investment in a given company, the foreign investor's motivation and purpose may be different. FDI can be made to start a completely new business abroad, commonly referred to as a greenfield investment, as well as in the full or partial acquisition of an existing business or in the form of a merger or takeover. FDI can be in three forms.

The first form is greenfield investment. Greenfield investments imply the creation of new subsidiaries in the host economies. Due to the reason that greenfield investments are made in new assets, it has a more favourable impact on economic growth than the other two types of FDI capital inflows. For the same reason, much more time is needed for greenfield investments projects implementation. This type of FDI investment is mostly targeted to less competitive markets and more frequently in developing economies. One of the difficulties in the measurement of greenfield investments is the time element, i.e. for how long a direct investment should be considered as greenfield investment. There are assumptions that an investment will cease to be classified as greenfield 4 to 5 years after the initial investment. However, there are no agreed standards on this and other related items (Bertrand, 2004).

The second form is extension of capacity. This type of FDI does not create a new economic activity, but develop already an existing one. It 
is an investment in previously established direct investment enterprises in the form of an increase in share capital or reinvested earnings. The extension of capacity of direct investment enterprises are at times confused with greenfield investments, while in both cases the underlying concept relates to the creation of new or additional capital stocks (Bertrand, 2004).

The third form is mergers and acquisitions. Mergers arise when two or more companies agree to combine into a single operation. While acquisitions involve the purchase of one company by another company. Mergers and acquisitions data are not identified as standard components within FDI. Nonetheless, there may be interest in such data because the nature of mergers and acquisitions may differ from other FDI, for example, they may not provide any new financing for the firms involved, but rather represent a change in investors (International Monetary Fund, 2009). The extension of capacity and mergers and acquisitions FDI is classified as brown field investments.

\section{Research methodology}

Given that there are no statistics on the establishment of new companies with foreign capital in Latvia (greenfield investments), as well as separate investments of capital increase and mergers and acquisitions (brownfield investment), there is a lack of data to answer the question, whether the current investment environment in Latvia is more favourable for foreign investors to buy local companies or establish new ones.

Based on the current $6^{\text {th }}$ edition of the IMF's Balance of Payments and International Investment Position Manual FDI definition (International Monetary Fund, 2009) and the theory discussed above, the author defined greenfield and brownfield investments as follows. The amount of share capital of a new company was considered to be a greenfield investment. First, when a foreign resident establishes a completely new company in Latvia and all $100 \%$ of the company's shares are owned by a foreign investor. In this case, the amount of share capital is greenfield investment. Secondly, when a foreign resident establishes a completely new company in Latvia together with a Latvian resident, but on the condition that the foreign investor owns at least $10 \%$ of the company's shares. In the second case, only the part of the share capital that belongs to the foreign resident is considered as FDI. While, brownfield investments were considered to be capital increase investments. Capital increase investments can be identified when a foreign resident, natural or legal person, invests in a company registered and operating in Latvia, provided that at least $10 \%$ of the shares of a company registered in Latvia that were previously owned by a Latvian resident were acquired. To 
paraphrase the above, the company's shares are sold and the ownership of the shares is changed. It is important to note that in this case no new economic activity is created. In the theory section, another type of incoming FDI was noted - merger and acquisition investments. Regarding this type of investment, due to the limited data, it is difficult to determine the situation when a company with foreign capital merges with a Latvian capital company and forms a new company. Thus, merger and acquisition investments are not analysed in this study. Based on this methodology, Lursoft IT Ltd specially selected the necessary data at the request of the author. Further analysis is based on data prepared by Lursoft IT Ltd. for period from 2005-2019 and Bank of Latvia data on foreign direct investment.

\section{Research results}

Foreign direct investment plays a significant role in the growth of Latvia's economy, but there is a noticeable degree of cyclicality in the intensity of the flows. The inflow of FDI in Latvia rapidly intensified after accession to the EU (see Figure 1). This was a positive signal for foreign investors, as by convincingly meeting all the Maastricht criteria, the Latvian state confirmed its readiness to integrate into a unified European economic system. It also confirmed its economic balanced development, as Latvia's performance in meeting the Maastricht criteria was well below the critical value.

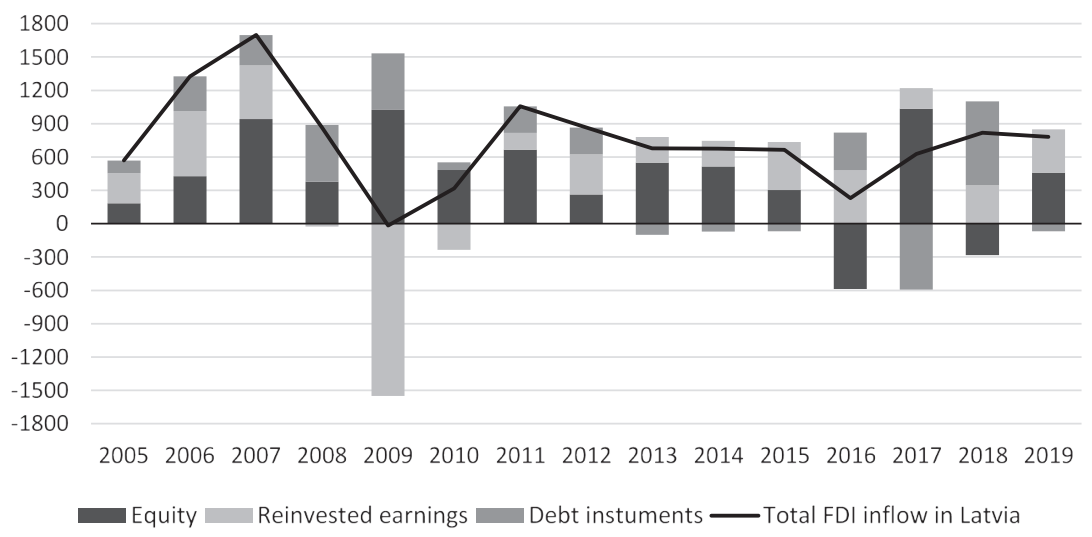

Figure 1. Net flows of foreign direct investment in Latvia, milion euro Source: author's compilation based on Bank of Latvia data

Since the restoration of Latvia's independence, Latvia has attracted 15,925 million euros of foreign direct investment. This corresponds to $52.3 \%$ of Latvia 's nominal GDP in 2019. Almost $80 \%$ of the accumulated 
FDIs were invested in the share capital of companies and reinvested in the development of the company, in other words, they were no-debt flows. This means that most of the incoming FDIs in Latvia were invested in the company's stock, capital shares, intellectual and real estate, thus promoting the growth of the Latvian economy and infrastructure development.

The amount of accumulated FDI in the form of debt instruments in 2019 was $20 \%$. Investments in debt instruments are reflected in the relationship between the direct investors and direct investment enterprises, which is affected by mutual acquisitions and disposals of debt securities issued by direct investors and direct investment enterprises. As soon as a "parent" or foreign investor company issues a loan to a "subsidiary", incoming and accumulated FDI increases. However, by repaying the loan to the "parent" company, the amount of FDI decreases. From an economic point of view, this is to be welcomed, as in this case the company is likely to expand or modernise its operations. However, loans need to be repaid and loan repayments mean an outflow of foreign direct investment. Accumulated FDI in the form of debt instruments has increased significantly from 584 million in 2000 to 3,239 million euro in 2019. However, the share of debt instruments in total accumulated FDI has gradually declined.

Until 2008 (years of rapid economic growth), the dominant flows were equity and reinvested earnings; other capital, which is loans among direct investors, were not the most significant. With the onset of the global economic and financial crisis, the flow of FDI decreased significantly, including in Latvia. Between 2008 and 2010, a large number of foreign-owned companies suffered losses. At the peak of the Latvian economic downturn in 2009, FDI losses amounted to 1,549 million euros. Thus, the inflow of FDI in that year was negative and amounted to -16 million euros.

After the economic crisis, FDI inflows were positive but modest. For example, the average inflow of FDI during the period from 2010 to 2013 was 729 million euros while the average flow before the economic crisis from 2005 to 2008 was 1,114 million euro. The situation was later exacerbated by the escalation of the military conflict between Russia and Ukraine. Increased political tensions in the region is one of the main negative factor that worsened the investment climate in all Baltic countries in 2014. In recent years, the inflow of FDI has fluctuated from 230 million euros in 2016 to 819 million euros in 2018. In 2019, the amount of FDI was 781 million which is broadly in line with the average investment dynamics over the last decade. In 2019, the total inflow of FDI was divided between equity investments (460 million euros), reinvested earnings (388 million euros), while the amount of debt instruments was negative (-67 million euros). 
Repatriation of profits to the investor's country of residence is considered in the scientific literature as a negative factor of FDI, therefore it is important to assess the amount of profits that remained in Latvia and were invested in the company's development and the share of dividends paid to foreign investors. Reinvested earnings are those parts of the enterprise's profits or losses which, according to the shareholding, belong to the direct investor. Thus, even if no new foreign direct investment enters Latvia, the amount of FDI may still change at the time of profit distribution. The company's operating profit increases FDI, but decreases it in the event of a loss or dividend payment. Figure 2 shows that the amount of dividends paid to direct investors has been stable even during the economic crisis period: 2009-2010.

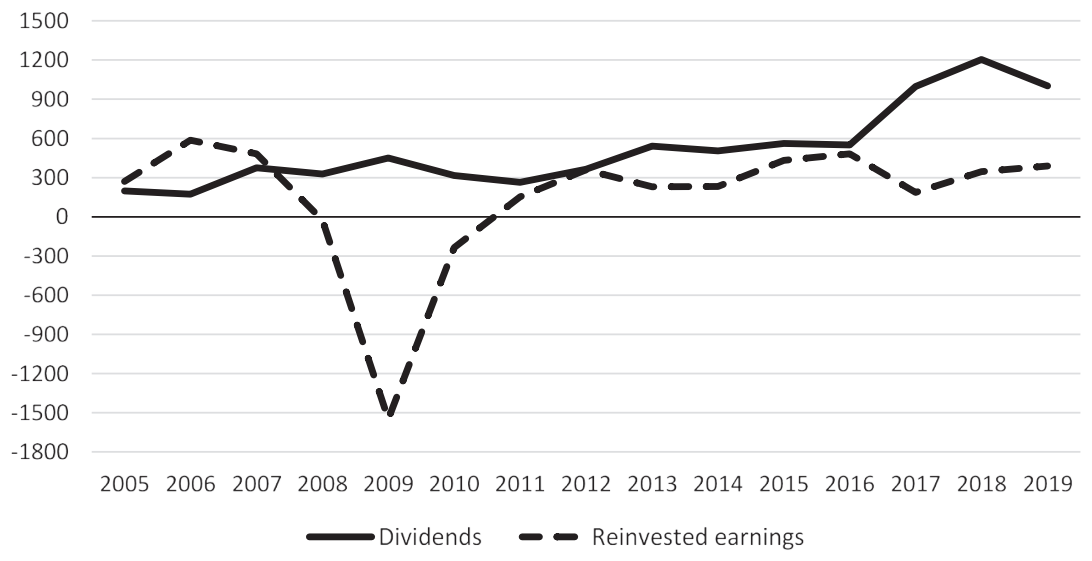

Figure 2. Amount of reinvested earnings of foreign direct investors and amount of dividends paid to foreign direct investors, million euro

Source: author's compilation based on Bank of Latvia data

Foreign direct investors received 1,074 million euros in dividends from 2005 to 2008, while the amount of incoming FDI in this period was 4,455 million euros. This means that for every euro invested, an average of 25 cents was paid out to direct investors in the form of dividends. However, from 2011 to 2014, this proportion changed significantly. During this period, 3,275 million euros of FDI flowed into Latvia, while the amount of dividends paid to direct investors amounted to 1,671 million euros, which means that approximately 51 cents of each foreign euro were returned to investors. In the period from 2015 to 2019, this proportion continued to increase in favour of dividend payments, and out of each euro invested, an average of 1.38 euro was paid to foreign investors in dividends. 
The growing amount of dividend payments is related to the amount of accumulated FDI. The amount of accumulated FDI in 2004 was 3.3 billion euros, in 2008 it was 8.1 billion euros, in 2014 it was 12.1 billion euros, and in 2019 - 15.9 billion euros. Undoubtedly, the invested capital cannot bring a profit immediately, but a higher accumulated capital also increases the actual profit, thus the amount of dividends also increases.

The payment of the large amount of dividends in recent years was also stimulated by the tax reform, which entered into force on 1 January 2018. The number of dividends paid to foreign direct investors in 2018 reached an all-time high (1,204 million euros). This amount of dividends is more than twice as high as in 2016, when the amount was 550 million euros. It should be noted that a significant increase in the amount of dividends paid was recorded before the tax reform in 2017, when 997 million euros were paid in dividends to direct investors. Such a rapid increase in the amount of dividends paid can be explained by the fact that discussions on tax reform were started already in 2016, but at the beginning of 2017 the main directions of tax reform were known. Tax reform aimed to increase interest rates on dividends paid from $15 \%$ to $20 \%$. It can be assumed that companies wanted to minimise their expenses by paying $15 \%$ tax on profits instead of the $20 \%$ rate that would be after 2018. The amount of dividends paid in 2019 decreased compared to the previous year, but was still at a high level and amounted to 1,001 million euros. In general, it should be noted that a year before and two years after the introduction of the tax reform, the amount of dividends paid to direct investors has increased significantly. In the period from 2018 to 2019, the average amount of dividends paid to foreign investors was 1,103 million euros per year, while the average amount of dividends in the five years prior to the introduction of the tax reform was 631 million euros per year.

The significantly higher amount of dividends paid since 2017 was also determined by the significantly higher amount of foreign-related corporate profits in this period. With the gradual improvement of the economic situation, the profits of foreign investors have been steadily increasing, from EUR 80 million in 2010 to EUR 1549 million in 2018 and EUR 1389 million in 2019. The change in the procedure for payment of corporate income tax had a positive effect on the amount of profit of foreign investor companies, but the record-high profit in 2018-2019 was largely determined by the favourable economic development in general.

The increase in the share of dividends in profit distribution also indicates that the amount of dividends paid has increased since 2017. In $2017,84 \%$ of the profit was paid in dividends and $16 \%$ was reinvested in the development of the company. In 2018, this proportion was $78 \%$ against $22 \%$, but in 2019 it was $72 \%$ and $28 \%$. In the period from 2012 to 2016 , or on average over five years, this proportion was $60 \%$ and $40 \%$, respectively. 
However, it should be taken into account that dividends can also be paid for the previous period, thus in this case it is not possible to precisely determine the direct impact of the change in the CIT payment procedure on the dividend payment.

In 2019, 21,228 companies with foreign capital were registered in Latvia. However, only $59 \%$ (or 12,435 of the total number) were engaged in economic activity. Most of the companies registered in Latvia with foreign capital, are fully owned by foreign residents. At the end of 2019, 74.5\% of economically active enterprises in Latvia with foreign capital were fully subsidised by foreign investors. $16.9 \%$ of cases, foreign investors held $50 \%$ or more of the company's capital shares, but less than $100 \%$. In only $8.6 \%$ of cases, these were Latvian and foreign joint ventures, where the share of foreign investor shares ranged from 10 to $50 \%$. Detailed statistics on the share of foreign direct investors' share capital and the aggregated business indicators of these enterprises (breakdown by years) are presented in Table 1 .

Table 1. FDI enterprises data in Latvia. Distribution of foreign direct investors in Latvia by share of equity and aggregated business indicators of these enterprises in 2005 and 2019

\begin{tabular}{|c|c|c|c|c|}
\hline \multirow{2}{*}{$\begin{array}{c}\text { Aggregated business indicators } \\
\text { of FDI enterprises }\end{array}$} & \multicolumn{4}{|c|}{ Distribution of foreign direct investors by share of equity } \\
\hline & $=<10 \%>50 \%$ & $=<50 \%>70 \%$ & $=<70 \%>100 \%$ & $100 \%$ \\
\hline \multicolumn{5}{|l|}{2005} \\
\hline Number of enterprises & 1678 & 1861 & 1087 & 8264 \\
\hline $\begin{array}{l}\text { Number of economically } \\
\text { active enterprises }\end{array}$ & 1201 & 1262 & 731 & 5210 \\
\hline $\begin{array}{l}\text { Number of economically } \\
\text { active enterprises with FDI } \\
\text { out of the total number of } \\
\text { enterprises with FDI, \% }\end{array}$ & $14.3 \%$ & $15.0 \%$ & $8.7 \%$ & $62.0 \%$ \\
\hline Turnover, EUR million & 2847 & 1375 & 2110 & 11187 \\
\hline Profit, EUR million & 375 & 109 & 93 & 291 \\
\hline \multicolumn{5}{|l|}{2019} \\
\hline Number of enterprises & 1381 & 1839 & 984 & 17024 \\
\hline $\begin{array}{l}\text { Number of economically } \\
\text { active enterprises }\end{array}$ & 1071 & 1375 & 726 & 9263 \\
\hline $\begin{array}{l}\text { Number of economically } \\
\text { active enterprises with FDI } \\
\text { out of the total number of } \\
\text { enterprises with FDI, } \%\end{array}$ & $8.6 \%$ & $11.1 \%$ & $5.8 \%$ & $74.5 \%$ \\
\hline Turnover, EUR million & 1351 & 1610 & 1850 & 21730 \\
\hline Profit, EUR million & 95 & 123 & 111 & 1029 \\
\hline
\end{tabular}

Source: author's calculations based on SIA "LURSOFT IT" data 
In the last fifteen years the dominance of foreign investors in companies registered in Latvia with foreign capital increased because in 2005, for example, the share of companies fully owned by foreign residents was $62.0 \%$. Thus, it can be concluded that foreign residents are increasingly choosing a corporate governance model where they have full control over the company. On the other hand, the management of companies together with a Latvian resident is not considered to be an attractive company management model.

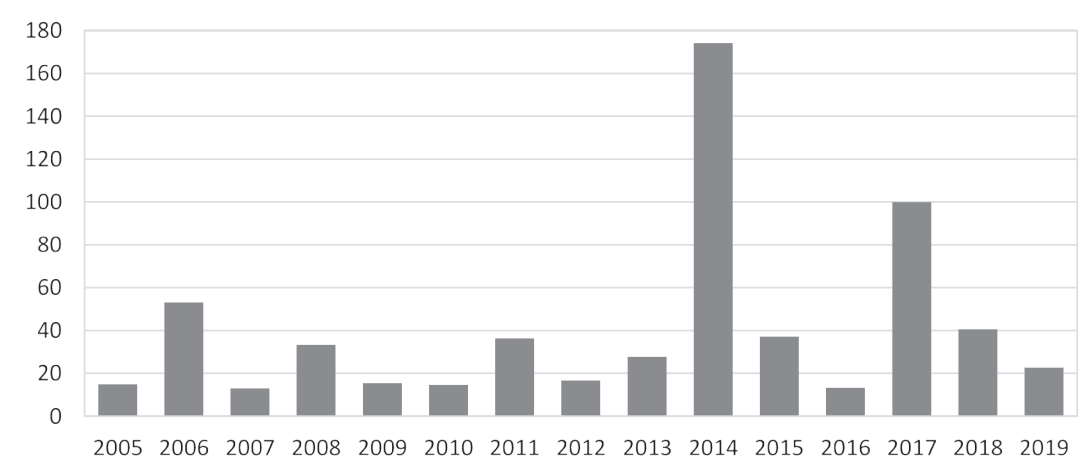

Figure 3. Inflow of greenfield investments in Latvia, million euro

Source: author's calculations based on SIA "LURSOFT IT" data

Regarding greenfield investments, Figure 3 shows the amount of foreign direct investors' investments in newly established companies in Latvia by years. In 2019, the amount of investments of foreign direct investors in companies established in 2019 was only 22.7 million euro. The volume of this type of investment was also weak in the previous years, thus it can be concluded that the amount of investments in foreign capital of a company established by a foreign investor in Latvia is insignificant compared to the amount of reinvested earnings. If the time factor is applied to greenfield investments and it is assumed that the amount of reinvested earnings within four or five years from the establishment of the company is also greenfield investments (if the company has made a profit during this period), then the total amount of greenfield investments is clearly higher. In the theoretical section, it was already been noted that one of the difficulties in analysing greenfield investments is the time factor, namely how long foreign direct investment should be considered as greenfield investments. It is assumed that these may be four or five years after the establishment of the company, but there is no common methodology of this aspect. Given that there is no common understanding among scientists about 
the time factor, the author classifies incoming greenfield investments as an investment in the share capital in the year of formation of the company. The small amount of greenfield investments in the reflected period is due to the fact that most of the largest foreign investors have been operating in Latvia for a long time, therefore the amount of greenfield investments of individual companies must be sought in the year of establishment of the company which might be in the 1990s.

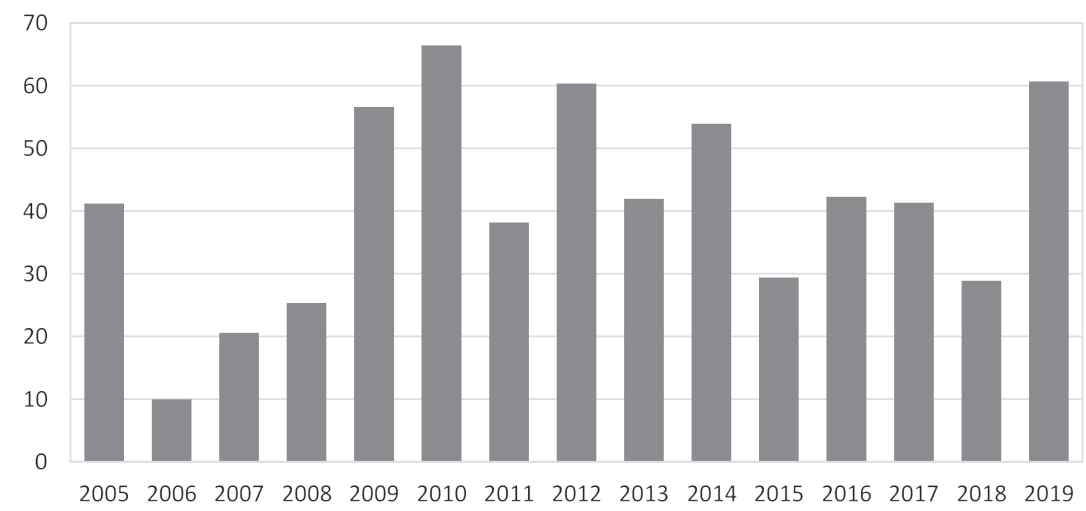

Figure. 4. Extension of capacity investments inflow in Latvia, million euro Source: author's calculations based on SIA "LURSOFT IT" data

Brownfield investments were considered to be capital increase investments. As can be seen in Figure 4, the amount of foreign direct investment with the aim of acquiring at least $10 \%$ or more from a company owned by a Latvian resident is quite volatile. In this way, investments became especially popular among foreign investors from 2009. Most likely, this is due to the fact that Latvian companies in difficulty during the crisis opted to choose to sell part or all of their shares to foreign residents, seeing no other opportunity for the company's development. On the one hand, this is to be seen in a negative light, as this type of FDI does not create new economic activity. If a foreign investor has acquired a controlling interest in the company, that is, $50 \%$ plus 1 share in the capital and more, further decisions on the development of the company, including the distribution of profits, will be made abroad. On the other hand, this type of investment also has a positive effect. First, the company and jobs are preserved. Secondly, a resident of Latvia retains capital which he/she can invest in setting up a new business. However, there is no doubt that incoming foreign direct investment, which is invested in existing companies, is less productive and less beneficial to economic development than greenfield 
investment. It should be noted that attributing the share of incoming FDI that went to the repurchase of domestic companies against FDIs in share capital, it can be concluded that this type of investment relative to total FDI in share capital has increased over the last fifteen years.

The financial crisis of 2008-2010 had a negative impact on economic activity in Latvia, thus the indicators of corporate earnings significantly deteriorated. Figure 5 shows that in 2008, companies that were wholly or partly owned by foreign direct investors suffered increased losses, reaching 600 million euros. That is more than the previous four years combined. In 2000 , the amount of losses was even higher and amounted to 672 million euros. From 2010 to 2014, the amount of losses gradually decreased. However, the number of companies that had losses in the reporting year has increased on the contrary (from 4874 companies in 2009 to 5224 companies in 2014). In 2017, the amount of losses in the reporting year reached 695 million euros, but the number of companies operating at a loss increased to 8287. Such results for 2017 and 2018-2019 (as the amount of losses was also significant in those years) can be explained as follows. Assessing the above results, the amount of profit of foreign direct investors (in recent years, foreign investors generally had a record amount of profit), it can be concluded that competition for market shares between foreign companies and local companies, as well as in the attraction of new consumers in Latvia is very high. Thus, there is a relatively large number of companies with foreign capital that operate at a loss in Latvia, do not withstand competition and are unable to successfully exist in the market.

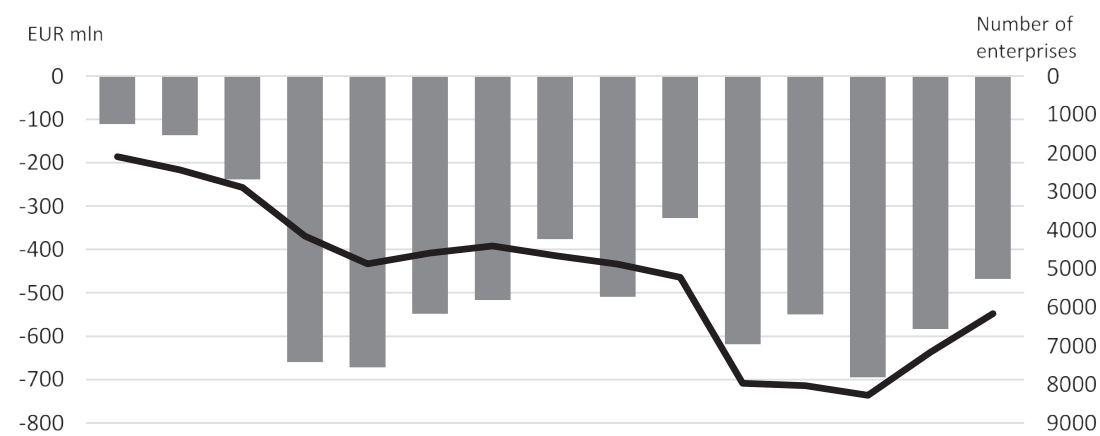

200520062007200820092010201120122013201420152016201720182019 The amount of loss, million euro Number of enterprises (right-hand scale)

Figure 5. Number of FDI enterprises operating at a loss and the amount of their losses in million euro

Source: author's calculations based on SIA "LURSOFT IT" data 
If a company with foreign capital is liquidated or the shares of a foreign resident are repurchased by Latvian residents, it means an outflow of foreign direct investment from the country. Figure 6 shows the number of companies and the amount of company shares in millions of euros that were sold to Latvian residents or liquidated. If in the early 2000s the outflow of FDI from Latvian-registered companies was small and related to legal factors, namely the protection of investors' rights and the fulfilment of contractual obligations, then in 2008-2010 the determining factor was the overall economic downslide. Starting from 2014, the investment environment both in Latvia and the other Baltic States was negatively affected by the deterioration of the geopolitical situation in the Eastern European region. Russia's illegal annexation of Crimea, EU-US sanctions against Russia and Russia's embargo on food imports from the EU and the US have destabilised the political and economic situation in the region.

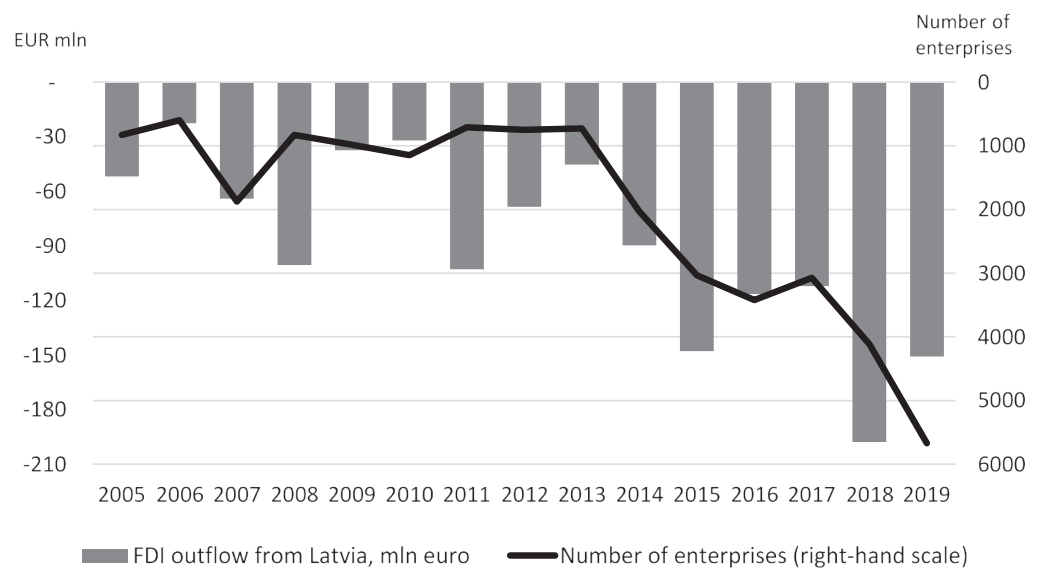

Figure 6. Outflows of FDI from Latvia in million euro and the number of FDI companies that reduced their share of equity

Source: author's calculations based on SIA "LURSOFT IT" data

In recent years, the largest outflow of FDI from Latvia has been recorded. Thus, in 2018, the amount of outflowing FDI from Latvia amounted to 198 million euros, but in 2019 - 151 million euros. The decision to reduce the share capital or liquidate the company in 2019 was made by a record number of foreign direct investors - 5,669 companies. The author has already pointed out that in recent years, despite the fact that foreign direct investors in Latvia generally worked at a profit, both the amount of losses and the number of companies operating at a loss increased at the same 
time. Consequently, the growing outflow of foreign direct investment from Latvia in recent years can be explained by a deterioration in profitability. Strong competition, rising labour costs that outpace productivity growth, a shortage of skilled labour and an aging population that narrows potential consumption in the medium and long term are the main reasons why foreign investors decide to leave the Latvian market.

In general, it can be concluded that volume of greenfield and brownfield investment is rather steady. However, the level of FDI in new projects is lower compared to the amount of reinvested earnings, due to the profit earned from operating activities in Latvia. The hypothesis of research is rejected. Investment environment in Latvia is favourable for FDI.

\section{Conclusions}

Foreign investors are diverse, and each has its own specific interests. Financial and strategic investors will be interested in completely or partially repurchasing an existing company or bank in order to increase the profit. Risk capital companies and investors invest in information and communications sectors and technological start-ups. Other foreign investors want to buy an existing company that already has a production process and supply chains in place to sell its products on the domestic market or export to other countries. Thus, in order to increase the amount of "green-field" investments and encourage foreign investors to reinvest more in the development of companies from the profits earned in Latvia, it is necessary to solve several structural problems.

Increasingly, it is not just countries that compete with each other to attract investment, but cities too; for example, when it comes to setting up some shared service centres or business process outsourcing centres. In this area, Riga often has to compete with Prague and other cities in Eastern Europe. The author notes that the range of available support mechanisms offered to entrepreneurs, including foreign investors, is wide, but the main ones are tax incentives. For example, special economic zones also exist in other European countries with favourable tax regimes. To attract more FDI, tax support mechanisms alone are not enough. As 55.0\% of Latvia's economically active population lives in Riga and Riga Region, it cannot be expected that, with the exception of the Riga region, other regions of Latvia will succeed in attracting FDI, especially to high-tech sectors.

In order to improve the investment environment in the Republic of Latvia and increase the inflow of "green-field" investments, it is necessary to reduce several obstacles. First, the size of the shadow economy needs to be reduced, as this will not only make economic and business processes more transparent, but will also increase tax revenues, thus increasing 
the economic flexibility needed to implement structural reforms. Secondly, structural unemployment needs to be reduced through targeted labour market and education system reforms and measures to promote innovation. Third, comprehensive reforms in the education and court system, speeding up court proceedings and legal improvements in the field of insolvency need to be pursued. Energy policy is also one of the topical issues on the agenda of entrepreneurs, as the disproportionately high payment burden of the mandatory procurement component on manufacturing companies does not promote the inflow of new foreign investment into Latvia's manufacturing industry, where FDIs are very important.

\section{REFERENCES}

Annual bulletin Latvia's Balance of Payments. Bank of Latvia. (2020). Retrieved 25 October 2020, from: https://datnes.latvijasbanka.lv/lmb/LMB_2019.pdf.

Balance of Payments and International Investment Position Manual. International Monetary Fund. (2009). Retrieved 10 November 2020, from: https:/www.imf.org/external/ pubs/ft/bop/2007/pdf/bpm6.pdf.

Bank of Latvia, (2020). Balance of Payments (BOP), International Investment Position (IIP) and International Trade in Services (ITS). Available at: https://statdb.bank.lv/lb/ Data/200 [Accessed 20.11.2020.].

Bertrand, A. (2004). Mergers and acquisitions, greenfield and extension of capacity. Direct Investment Technical Group. Retrieved 10 October 2020, from: https://www. imf.org/external/np/sta/bop/pdf/diteg42829.pdf.

Buckley, P. J., Casson, M. (2009). Internalisation Theory of the Multinational Enterprise: A Review of the Progress of a Research Agenda after 30 year, Journal of International Business Studies, 40(9), 1563-1580.

Buckley, P. J., Casson, M. (1976). The Future of the Multinational Enterprise, Palgrave Macmilian UK.

Casson, M. (2000). Enterprise and leadership: Studies on firms, networks and institutions. Cheltenham: Edward Elgar.

Dunning, J., Lundan, S. (2008). Multinational Enterprises and The Global Economy. Edward Elgar Publishing Limited, UK.

Dunning, J. (2001). The eclectic (OLI) paradigm of international production: past, present and future, International Journal of the Economics of Business, 8(2), 173-190.

Dunning, J. (1988). The eclectic paradigm of international production: A restatement and some possible extensions, Journal of International Business Studies, 19(1), 1-31.

Fahy, J., Shipley, D., Neale, C. (1998). Motives and experience of international joint venture partners in Hungary, Journal of Business \& Industrial Marketing, 13(2), 155-165.

Hayek, F. (1941). The Pure Theory of Capital. The Ludwig von Misses Institute. Alabama. Retrieved 12 October 2020, from: https://cdn.mises.org/Pure\%20Theory\%20of\%20 Capital_4.pdf 
Hennart, J. F. (2009). Down with MNE-centric Theories! Market Entry and Expansion as the Bundling of MNE and Local Assets, Journal of International Business Studies, 40(9), 1432-1454.

Hill, C. W. L. (2007). International Business: Competing in The Global Marketplace. Irwin - McGraw-Hill, New York.

Investment Climate Reforms. An Independent Evaluation of World Bank Group Support to Reforms of Business Regulations. World Bank Group. (2015). Retrieved 28 October 2020, from: https:/ieg.worldbank.org/sites/default/files/Data/Evaluation/files/investment_climate_final.pdf.

Javorcik, B. S. (2004). Does Foreign Direct Investment Increase the Productivity of Domestic Firms? In Search of Spillovers through Backward Linkages, The American Economic Review, 94(3), 605-627.

Johnson, A. (2006). The Effect of FDI inflows on Host Country Economic Growth. Working Paper Series in Economics and Institutions of Innovation, 58.

Kahraman, C. (2011). Investment decision making under fuzziness, Journal of Enterprise Information Management, 24(2), 126-129.

Keynes, J. M. (1936). The General Theory of Employment, Interest and Money. Centre for Comparative and International Studies. Retrieved 2 October 2020, from: https:// www.files.ethz.ch/isn/125515/1366_KeynesTheoryofEmployment.pdf.

Narula, R. (2012). Do We Need Different Framework to Explain Infant MNEs from Developing Countries? Global Strategy Journal, 2(3), 188-204.

Oxelheim, L. (1993). The Global Race for Foreign Direct Investment: Prospects For The Future. Springer-Verlag Berlin Heidelberg.

Pike, R., Neale, B. (2006). Corporate Finance and Investment. Pearson Education Limited, England.

Ribau, C., Raposo. M., Moreira. A. (2015). Internationalisation of the firm theories: A schematic synthesis, Int. J. Business and Globalisation, 15(4), 528-554.

Shadow Economy Index for the Baltic Countries. Stockholm School of Economics. (2020). Retrieved 12 November 2020, from: https://www.sseriga.edu/shadow-economyindex-baltic-countries.

Shenkar, O. (2007). Foreign Direct Investment Theory and Application. Retrieved 15 October 2020, from: http://www.sagepub.com/sites/default/files/upm-binaries/ 18594_Chapter_3.pdf.

Verbeke, A., Kano, L. (2012). An Internalization Theory Rationale for MNE Regional Strategy, Multinational Business Review, 20(20), 135-152.

Verbeke, A., Kano, L. (2015). The New Internalization Theory and Multinational Enterprises from Emerging Economies: A Business History Perspective, The Business History Review, 89(3), 415-445.

Vernon, R. (1966). International investment and international trade in the product cycle, Quarterly Journal of Economics, 80(2), 190-207. 